\title{
Structural Behaviors of High Temperature Steel Frame Rapidly Cooled by Spray Water
}

\author{
Yunchun XIA \\ School of Civil Engineering \\ Anhui Jianzhu University \\ Hefei, China \\ e-mail: wxiayc@126.com
}

\author{
Zhengchao XU \\ School of Civil Engineering \\ Anhui Jianzhu University \\ Hefei, China \\ e-mail: zxc87391258@163.com
}

\begin{abstract}
During rapid cooling by spray water in fire fighting, the deformation of high temperature structural steel was different, it was mainly influenced by water and the steel structure itself temperature. Its bearing capacity was controlled by lower beam flange, and the joint bearing capacity was controlled by T-type plate. The beam temperature had a large effect on its failure mode. The yield and ultimate loads, they reduced about $6.1 \%$ and $9.6 \%$ between cooled from $400^{\circ} \mathrm{C}$ and $600^{\circ} \mathrm{C}$, and its ultimate displacement reduced around $9.3 \%$, its rotational angle increased about $15 \%$. But their yield and ultimate loads reduced about $26.0 \%$ and $24.1 \%$ between cooled from $400^{\circ} \mathrm{C}$ and $650^{\circ} \mathrm{C}$, and its ultimate displacement reduced about $18.4 \%$.
\end{abstract}

Keywords-steel structure; rapid cooling; structural behavior; high temperature; spray water

\section{INTRODUCTION}

In recent years, many steel structure buildings have been built in China. In fire fighting, rapid cooling by spray water would produce a large temperature difference inside of high temperature steel structure, which would produce very large local stress inside of the structure. Many researchers [1-10] had studied on the thermal and mechanical coupling rules for restrained steel column in fire and natural cooling in air. During rapid cooling, its axial tension increased with the rising of cooling rate, and axial force was very large, once cooling water sprayed improperly, the stress at local cooling area were much larger than those during heating-up, but its plastic deformation could not recover. For the axially restrained component, its stress could exceed the yield strength. The large stress might cause the structure to yield or fail in short time. Therefore, this research could provide a reference for steel structure design.

\section{EXPERIMENTAL IN DETAILS}

The detailed dimension of test specimen was shown in Fig.1; the test system was shown in the Fig.2. Layout of the measuring system was shown in Fig.3.

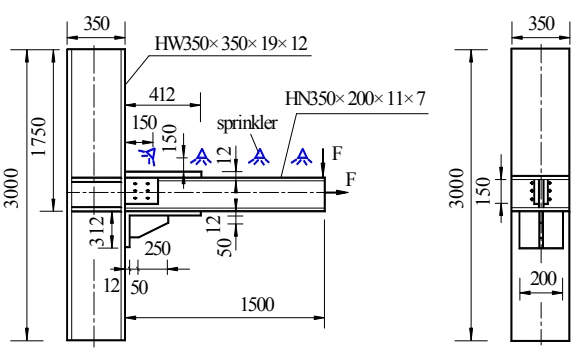

(a) Dimension of test specimen

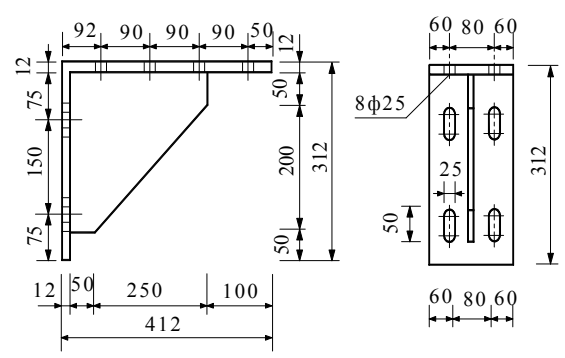

(b) Dimension of T-type plate
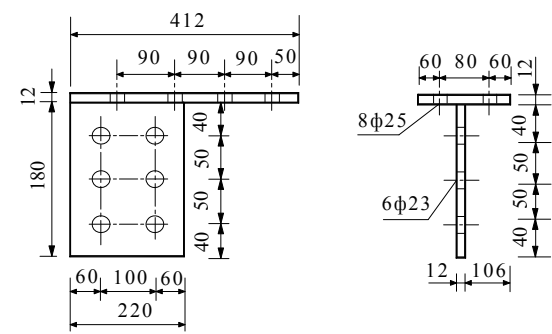

(c) Dimension of L-type plate

Figure 1. Dimension of test specimen

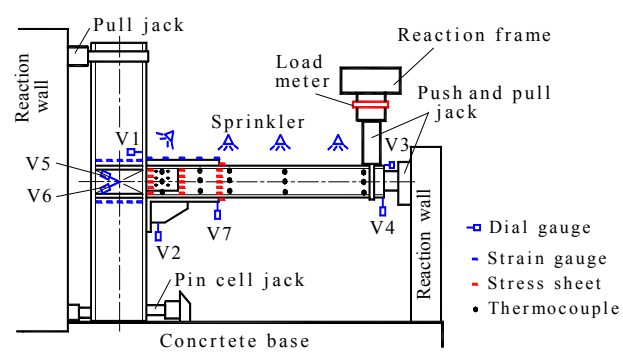

Figure2. Sketch for test system 


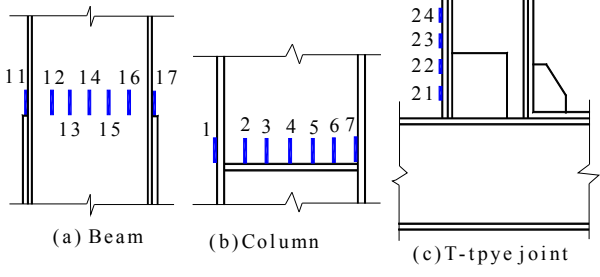

Figure 3. Layout sketch of strain gauges

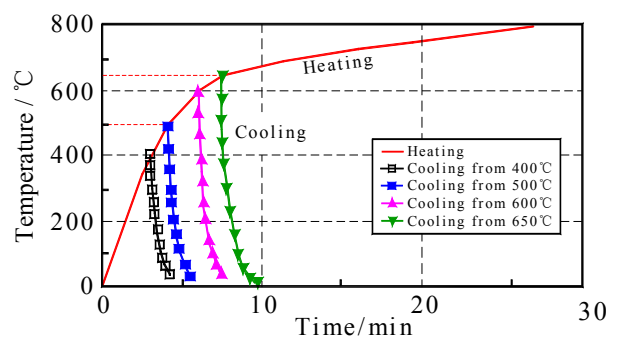

Figure 4. Average temperature change of the structure

All the components were connected by high-strength bolts. The T-type plate below beam was connected with beam by eight M24 high-strength bolts, their strength was at 10.9 grade, its pre-tension was $225 \mathrm{kN}$, the corresponding torque was about $780 \mathrm{~N} \cdot \mathrm{m}$. The L-type horizontal plate was fixed on beam upper flange by eight M24 high-strength bolts at 10.9 grade, its pre-tension was also $225 \mathrm{kN}$, and its vertical plate was fixed on the beam web by six M22 high-strength bolts at 10.9 grade, its pre-tension was $190 \mathrm{kN}$, the corresponding torque was about $600 \mathrm{~N} \cdot \mathrm{m}$. Before test, the pre-tension was loaded in the order from corner to center. During screwing bolts, the loaded screwing torque on each bolt was about $50 \%$ of the overall torque at first, after that for all bolts, the other $50 \%$ torques was loaded again in the same order. At horizontal direction, beam was fixed by a push-pull jack so as to ensure its stability, and its bottom end was connected with column by four high-strength screws, and the screw strength was at 8.8 grade. The beam was loaded by a jack; its maximum load was $600 \mathrm{kN}$.

When heating-up, its temperature could be elevated according to ISO-834 standard or self-designed rate. There was vertical loading jack above its top; the maximum load of each jack was $3000 \mathrm{kN}$. In test, when the test specimen was heated up to the set temperature, then its burning kept for about $10 \sim 15$ minutes to ensure all part temperature in balance. And then load was acted on the test specimen until it failed, and the loading rate was $10 \mathrm{kN} / \mathrm{s}$. At the same time, the water spray system started to spray for cooling until test specimen was cooled to near ambient temperature. Spray water was supplied by a high-pressure water pump. The nozzle was fixed above $15 \mathrm{~cm}$ far from beam upper flange and $15 \mathrm{~cm}$ far from the column. Water flow was measured by an orifice flow-meter (in test, water flow was about $0.036 \mathrm{~m}^{3} / \mathrm{min}$ for each nozzle), and water temperature at outlet of the nozzle was measured by a thermal couple. In heating-up and rapid cooling, the average temperature of test specimen was shown in Fig.4.

\section{THE MECHANICS AND DEFORMATION}

When the test specimen was cooled from different temperature by spray water at $25.6^{\circ} \mathrm{C}$, its Mises stress and deformation at different stage were shown in Fig.5.

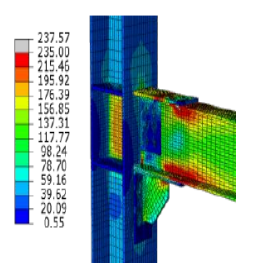

(a) Elastic stage

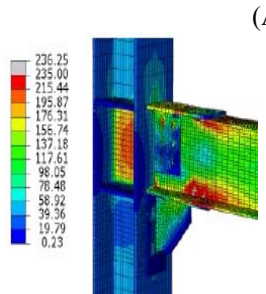

(a) Elastic stage

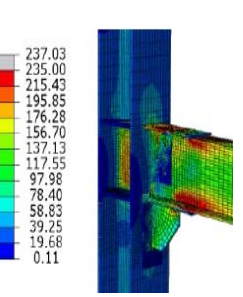

(a) Elastic stage

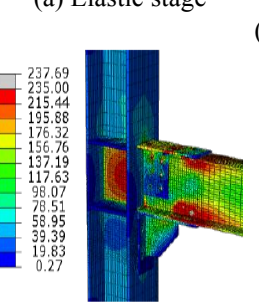

(a) Elastic stage

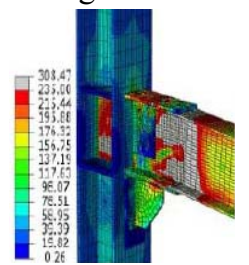

(b) Plastic stage

A) Cooling from $400^{\circ} \mathrm{C}$

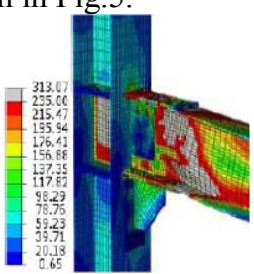

(c) Ultimate status

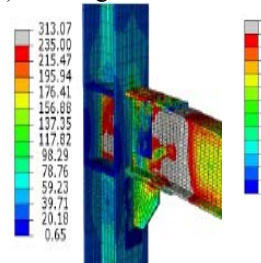

(b) Plastic stage

(B) Cooling from $500^{\circ} \mathrm{C}$

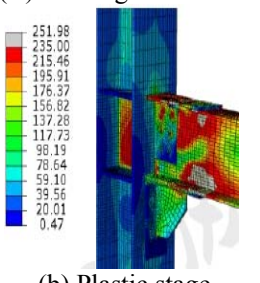

(b) Plastic stage

(C) Cooling from $600^{\circ} \mathrm{C}$

\section{C) Cooling from $600^{\circ} \mathrm{C}$}

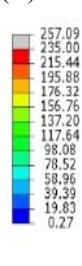

(b) Plastic stage

(D) Cooling from $650^{\circ} \mathrm{C}$

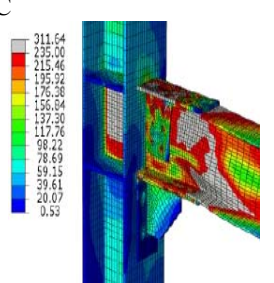

(c) Ultimate status

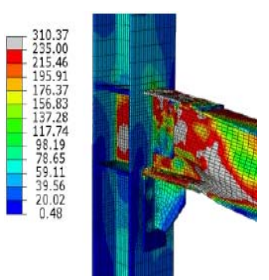

(c) Ultimate status
Figure 5. Miese stress and deformation at different stage

For the failure mode of the above test specimen, when it was cooled from $400^{\circ} \mathrm{C}$, the bolt holes in outer row of beam flange enlarged, and bolts slipped slightly, beam web banged out slightly, beam web had larger banging out. When cooled from $600^{\circ} \mathrm{C}$, the upper and lower beam flange buckled, beam web was largely banging out. When cooled from $650^{\circ} \mathrm{C}$, the joint of horizontal and vertical parts of Ltype plate was pulled off, beam web and flange was serious banging away.

When the structure was cooled from $600^{\circ} \mathrm{C}$ and cooled by spray water at $25.6^{\circ} \mathrm{C}$, the failure modes near the joint were shown in Fig.6. 


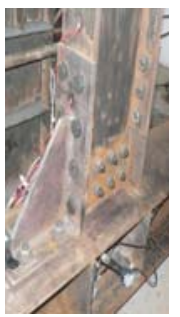

(a) $400^{\circ} \mathrm{C}$

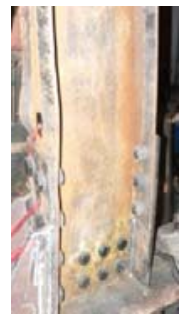

(b) $500^{\circ} \mathrm{C}$

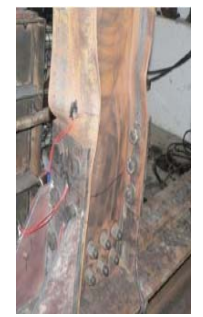

(c) $600^{\circ} \mathrm{C}$

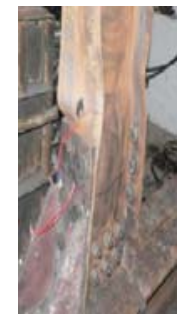

(d) $650^{\circ} \mathrm{C}$
Figure 6 . Failure mode after cooling from different temperature

When temperature of test specimen was below $600^{\circ} \mathrm{C}$, it mainly was the failure of bolt holes at outer row of the beam flange, and the failure mode was the sectional tearing or pulling off around the bolt holes, the beam flange warped obviously. When rapidly cooled from $650^{\circ} \mathrm{C}$, the upper and lower beam flange produced significant warpage. Compared the above simulation results, when the structure temperature was below $600^{\circ} \mathrm{C}$, the difference of failure stress was very small during cooling. However, when the structure reached $650^{\circ} \mathrm{C}$ and cooled spray water at the same temperature, its yield stress was much less, it was lower around $15.6 \%$ than that of the structure cooled from $600^{\circ} \mathrm{C}$.

\section{STRAINS OF BEAM AND COLUMN}

\section{A. Strain at Beam Web}

When the structure was heated up to different temperature, and then it was cooled by spray water at $25.6^{\circ} \mathrm{C}$, the local strain of beam web was shown in Fig.7.

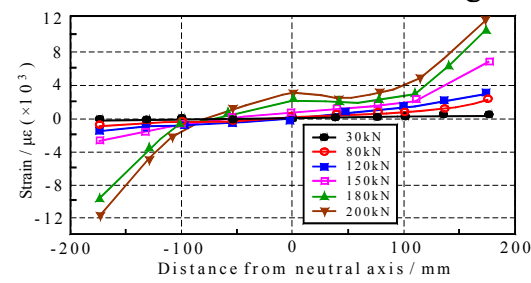

(a) Cooling from $400^{\circ} \mathrm{C}$

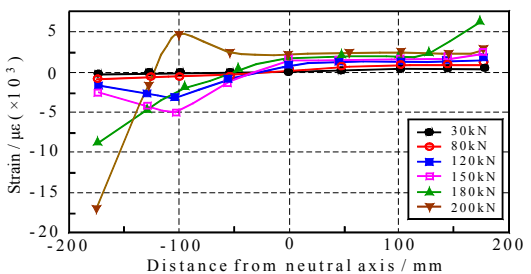

(b) Cooling from $500^{\circ} \mathrm{C}$

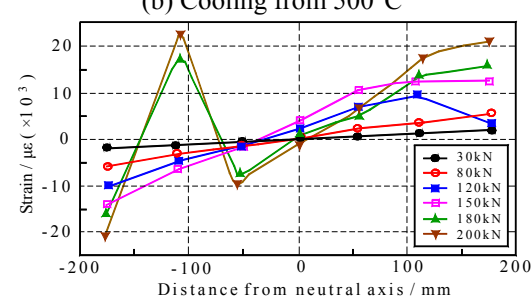

(c) Cooling from $600^{\circ} \mathrm{C}$

Figure 7. The strain of beam at different location

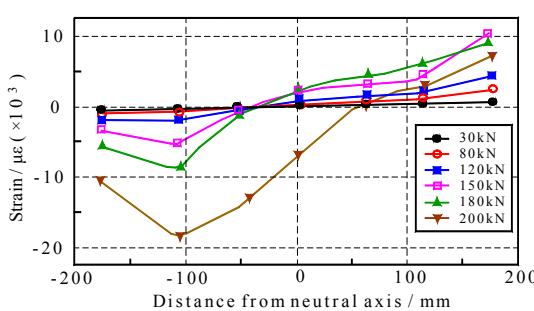

(d) Cooling from $650^{\circ} \mathrm{C}$

Figure 7. The strain of beam at different location

In early loading, beam was elasticity, its strain basically fitted for the plane assumption. When load increased and it became the plasticity, the strain no longer met with the plane assumption, the strain increased sharply at $-104 \mathrm{~mm}$ far from neutral axis, beam yielded seriously, and the web had obvious banging away. Compared the above test specimens, their strains were obviously different when cooled from $500^{\circ} \mathrm{C}, 600^{\circ} \mathrm{C}$ and $650^{\circ} \mathrm{C}$ respectively, and the banging direction was different. But the strain of beam flange was the largest at $400^{\circ} \mathrm{C}$, the strain at beam neutral axis was also larger, that indicated its flange yielded seriously, banging at the centerline of web was obvious.

\section{B. Strain of Stiffened Plate}

When the steel frame was cooled at different temperature and cooling water was at $25.6^{\circ} \mathrm{C}$, its strains at different location and different loads were shown in Fig.8.

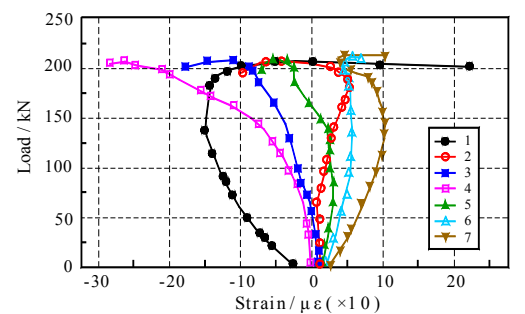

(a) Cooling from $400^{\circ} \mathrm{C}$

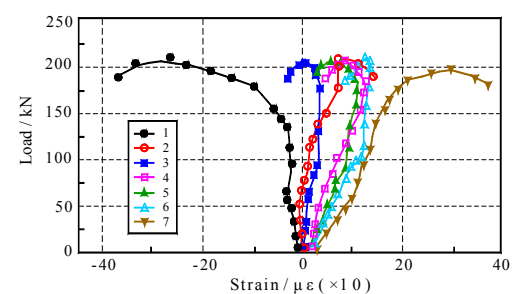

(b) Cooling from $500^{\circ} \mathrm{C}$

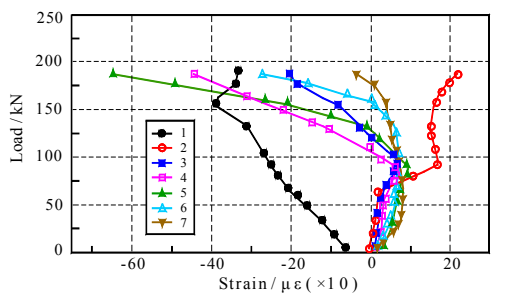

(c) Cooling from $600^{\circ} \mathrm{C}$

Figure 8 . Relation between strain and load at the section of beam 


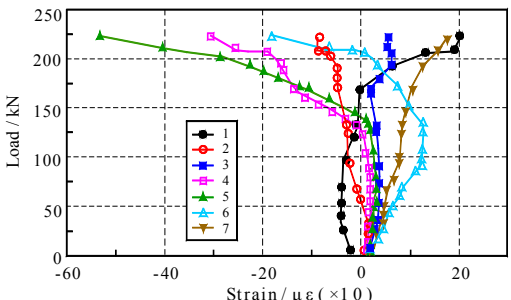

(d) Cooling from $650^{\circ} \mathrm{C}$

Figure 8 . Relation between strain and load at the section of beam

When the load was below $150 \mathrm{kN}$, strain increased approximately in linear, and the strain of flange was much larger than that of web. But when the load reached $200 \mathrm{kN}$, strains at all four beams had mutation after beam web was banging away, but its regularity was not obvious. The reason might be that the web banging and flange warpage made the force, and strain gauges at beam flange were not at the center.

\section{Strain of Column at Different Loading}

When cooling water was $25.6^{\circ} \mathrm{C}$, Strains of beam section at different load were shown in Fig.9.

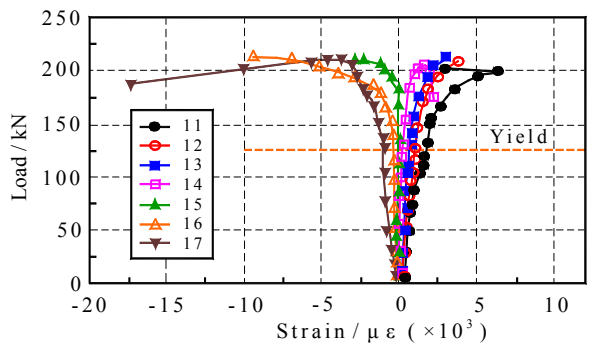

(a) Cooling from $400^{\circ} \mathrm{C}$

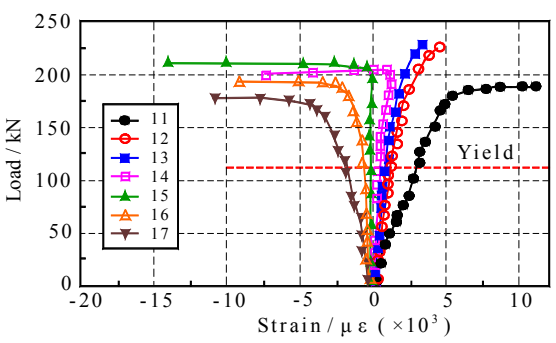

(b) Cooling from $500^{\circ} \mathrm{C}$

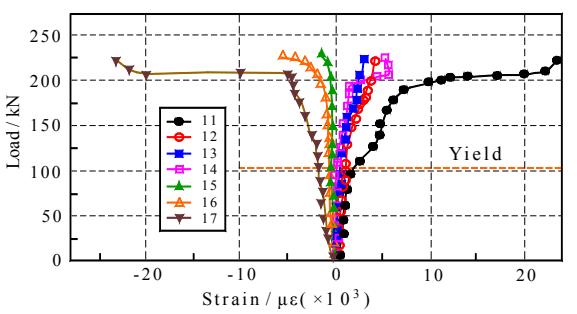

(c) Cooling from $600^{\circ} \mathrm{C}$

Figure 9. Relation between strain and load at the section of beam

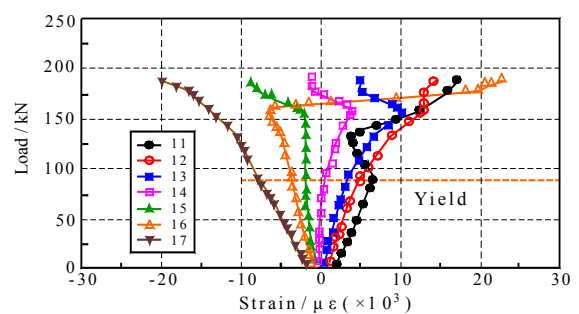

(d) Cooling from $650^{\circ} \mathrm{C}$

Figure 9 . Relation between strain and load at the section of beam

At elastic stage, the largest strain was at the upper and lower flanges, the strain at the closer point to neutral axis was relatively smaller. At the plastic stage, the strain of flange increased rapidly, and it was much larger than that of web, that could cause its flange to warp significantly, when the load reached about $200 \mathrm{kN}$, the strain sharply changed at No.16 gauge. When cooled at $650^{\circ} \mathrm{C}$, and it also quickly exceeded the strain of flange, its web produced outer banging. When cooled at $600^{\circ} \mathrm{C}$, failure happened at horizontal L-plate.

\section{Strain of the Horizontal Plate on Beam}

When the specimen was cooled by water at $25.6^{\circ} \mathrm{C}$, the strains at lateral plate were shown in Fig. 10.

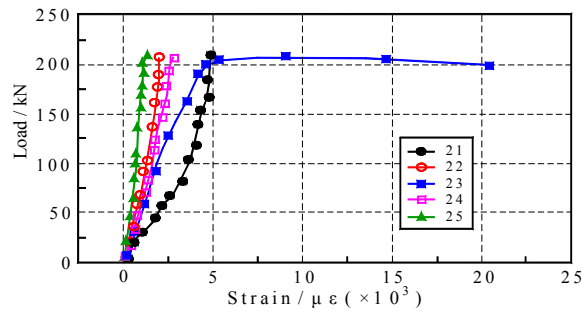

(a) Cooling from $400^{\circ} \mathrm{C}$

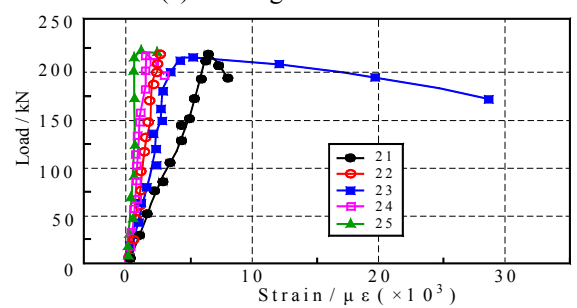

(b) Cooling from $500^{\circ} \mathrm{C}$

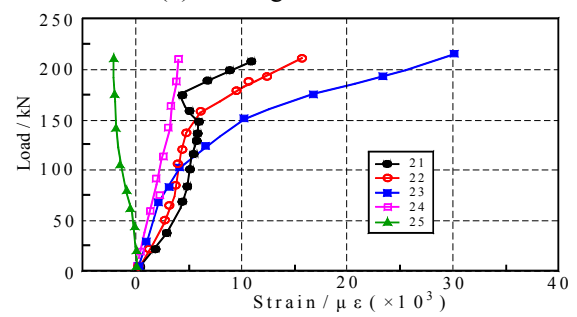

(c) Cooling from $600^{\circ} \mathrm{C}$

Figure 10. Strain at different location of the lateral plate 


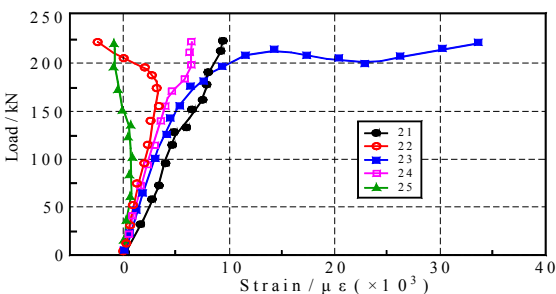

(d) Cooling from $650^{\circ} \mathrm{C}$

Figure 10. Strain at different location of the lateral plate

When cooled from different temperature, the strain of lateral plate had the same developing trend. When the load reached $100 \mathrm{kN}$, the test specimen was still at elastic range, but the strain at gauge 23 began to suddenly increased, and they could reach about $5000 \mu \varepsilon$. However, strains at the other parts were relatively small. When the load reached $150 \mathrm{kN}$, the strain, whose location was $240 \mathrm{~mm}$ far from beam flange, rapidly grew, while strains at other parts basically no longer grew, a plastic hinge produced here, and the lateral plate had produced centralized deformation at that location.

\section{CONCLUSIONS}

When test specimen was rapidly cooled by spray water from different temperature, its bearing capacity was controlled by lower beam flange, and the joint bearing capacity was controlled by T-type plate. The beam temperature had a large effect on its failure mode. When the steel beam was cooled from $400^{\circ} \mathrm{C}$, the bolt holes in outer row of beam flange enlarged, and bolts slipped slightly, beam web banged out slightly, beam web banged outwards. When cooled from $600^{\circ} \mathrm{C}$, the upper and lower beam flange buckled, beam web was largely banging out. When cooled from $650^{\circ} \mathrm{C}$, the joint of horizontal and vertical parts of Ltype plate was pulled off, the fracture gap between lower beam flange and column was larger, beam web and flange was serious banging away. The yield stress reduced when beam temperature increased. Simultaneously, the beam temperature had a large effect on its bearing capacity, its yield and ultimate loads, they reduced about $6.1 \%$ and $9.6 \%$ between cooling from $400^{\circ} \mathrm{C}$ and $600^{\circ} \mathrm{C}$, but they increased to about $26.0 \%$ and $24.1 \%$ between cooling from $400^{\circ} \mathrm{C}$ and $650^{\circ} \mathrm{C}$.

\section{ACKNOWLEDGMENT}

This work was financially supported by the National Natural Science Foundation of China (Grant No. 51478002).

\section{REFERENCES}

[1] LI Guo-qiang, "Analysis of restrained steel beams subjected to temperature increasing and descending," Journal of Disaster Prevention and Mitigation Engineering, Vol.32, pp.242-251, 2006.

[2] Yunchun XIA, "Damaged behavior of high temperature steel frame structure rapidly cooled by spray water in fire," Building Structure, vol.46, pp.583-590, 2016.

[3] L. Gardner, N.R. Baddoo, "Fire testing and design of stainless steel structures," Journal of Constructional Steel Research, vol.62, pp.532$541,2006$.

[4] Y.C.Wang, J.M.Davies, "An experimental study of non-sway loaded and rotationally restrained steel beam assemblies under fire condition: analysis of test results and design calculations," Journal of Constructional Steel Research, vol.59, pp.291-296, 2003.

[5] Aristizabal-Ochoa JD, "Stability and second-order non-linear analysis of 2D multi-beam systems with semirigid connections: Effects of initial imperfections," International Journal of Non-linear Mechanics, vol.47, pp.537-546, 2011.

[6] Bailey, "Numerical modeling of structural fire behavior of restrained steel beam-beam assemblies using typical joint types," Engineering Structures, vol.32, pp.2337-2251, 2010.

[7] Hozjan T., Planinc I., "Buckling of an axially restrained steel beams under fire loading," International Journal of Structural Stability and Dynamics, vol.11, pp.451-456, 2011.

[8] Leonard Y Cooper, "The interaction of an isolated sprinkler spray and a two-layer compartment fire environment," International Journal of Heat and Mass Transfer, Vol.38, pp.1115-1126, 1995.

[9] Bailey C.G, "The influence of the thermal expansion of beams on the structural behavior of beams in steel-framed structures during a fire, Engineering Structures, Vol.22, pp.755-769, 2000.

[10] Wang Y C., "Post-buckling behavior of axially restrained and axially loaded steel beams under fire condition," Journal of Structural Engineering, vol.130, pp.371-379, 2000.

[11] Franssen JM, Cooke GME, Latham DJ.", Numerical Simulation of a Full Scale Fire Test on a Loaded Steel Framework," Journal of Constructional Steel Research, vol.51, pp.1199, 1995.

[12] XU Xiaoling, YAO Bin, WANG Hanjie, "Water density probability distribution and fire control capability of sprinkler system," Fire Safety Science, vol.18, pp.154, 2009. 